\title{
Climate-Smart Chocolate
}

\begin{abstract}
Ghana, Ivory Coast and Indonesia are the major cocoa producers, with smallholder farmers in West Africa being responsible for around 60 per cent of global supply. Each year in the UK alone we consume around 500,000 tonnes of chocolate as bars and drinks, in cakes and biscuits. The average 40 -gram bar of milk chocolate will carry with it a carbon footprint of around 200 grams. In the UK an estimated 18,000 tonnes of chocolate and sweets are wasted each year, responsible for around 90,000 tonnes of greenhouse gas emissions. High temperatures and drought can have severe impacts on cocoa yields, with Ghana likely to see suitable areas for cocoa pushed south as more northern areas become drier and hotter. Diseases like cocoa swollen shoot virus are already a major concern with around 300 million trees thought to be infected. Rehabilitation and renovation of existing cocoa plantations is at the heart of building resilience to climate change and securing the millions of livelihoods that depend on cocoa.
\end{abstract}

Keywords Ghana $\bullet$ Cote D'Ivoire $\bullet$ Cocoa $\bullet$ Agroforestry $\bullet$ Renovation $\bullet$ Rehabilitation $\bullet$ Disease resistance

Chocolate. A joy. To unwrap a smooth bar at break time and feel that boost in mood and energy [1]. As a child I was obsessed with the stuff. It was a rare treat with Christmas and Easter being the delectable chocolate

(C) The Author(s) 2019

D. Reay, Climate-Smart Food, https://doi.org/10.1007/978-3-030-18206-9_6 
oases that shimmered in my dreams for months in advance. On 1 December each year an Advent calendar would be ceremonially pinned to the kitchen wall, with a small chocolate hidden behind each cardboard door. Having three siblings meant the privilege of opening a door, and eating the glossy treat behind, fell every four days; six chocolates in all for Advent and every one of them savoured as a precious delicacy. Christmas Day itself meant still more chocolatey delights to be hoarded and bartered with. The importance of chocolate to these family festivals was most apparent when it was absent. One tearful Easter Sunday our mum brought down the carefully hidden box containing that year's longed-for chocolate eggs. Mice had eaten everything but the foil wrappers!

Chocolate and its key ingredient—cocoa—remains a beloved foodstuff around the world. As bars and biscuits, in cakes and drinks, we collectively consume over 7 million tonnes of chocolate each year in a global market worth around $\$ 100$ billion [2]. Western nations lead the way in terms of amounts consumed, with the US at 5.5 kilograms per person per year, and the British, Germans and Swiss vying for global chocoholic title at over 8 kilograms per person [3]. None of these major chocolate-consuming nations have a climate suitable for cocoa production.

Cocoa is produced by the seeds and pods of a tree called Theobroma cacao. Native to the tropical zone of Central and South America, chocolate's journey to become today's global food essential can be traced back to $400 \mathrm{BC}$ as a drink of Mayan traders in Costa Rica [4]. Apparently it took many years to catch on in the West as, without something to sweeten it, it tasted horrible.

Cocoa trees are now grown in a wide tropical belt spanning central and southwest Africa, South and East Asia, and much of South America. They require average temperatures of 18 to 30 degrees Celsius and, most importantly, plentiful rainfall throughout the year [4]. Ghana, Ivory Coast and Indonesia are the major producers, with smallholder farmers in West Africa being responsible for around 60 per cent of global supply (Fig. 6.1) [5].

The chocolate that enfolds our own Scottish break-time treat started life as cocoa beans in Ghana. These beans are used to produce both cocoa butter and cocoa liquor, with on-farm emissions (mainly due to the use of nitrogen fertilisers) and the processing phase (due to diesel use for roasting beans) being the main sources of greenhouse gas from the chocolate industry in Ghana [7]. 
Cocoa bean production, 2014

Annual cocoa bean production, measured in tonnes per year.

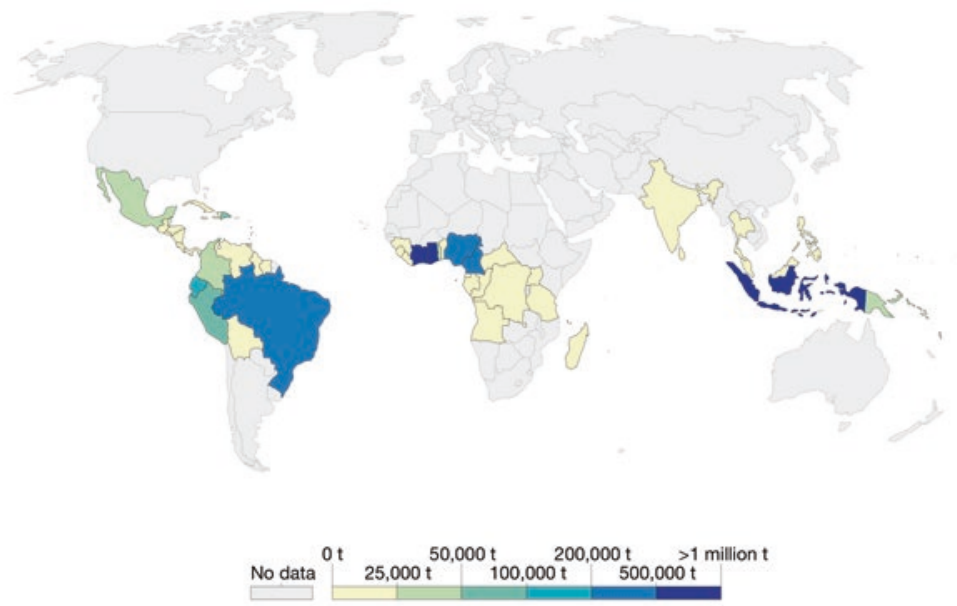

Fig. 6.1 Global cocoa bean production in 2014 by country of origin (Source: Hannah Ritchie, Our World in Data) [6]. Available at: https://ourworldindata. org/grapher/cocoa-bean-production

Chocolate's overall carbon footprint is an international pick ' $n$ ' mix of this initial cocoa production and processing, its transport around the world and the extra emissions due to the milk, sugar, palm oil and other ingredients that are then added to make the chocolate we know and love. The average 40 -gram bar of milk chocolate will carry with it a carbon footprint of around 200 grams (or upwards of 5 kilograms per kilogram of chocolate). This rises to nearer 300 grams for a bar of dark chocolate due to the extra cocoa it contains.

Our chocolate, then, is a lovely but high-emission food. Each year in the UK alone we consume around 500,000 tonnes of it as bars and drinks, in cakes and biscuits [3]. Some 8 million of us eat it every day of the week and bars of solid milk chocolate are the nation's favourite [8]. The associated climate impact of British chocolate addiction is similarly huge, at around 2.5 million tonnes of greenhouse gas per year. 
Chocolate is precious stuff, yet remarkably a significant amount of it never gets eaten. In the UK an estimated 18,000 tonnes of chocolate and sweets are wasted each year [9]. This avoidable waste is mainly due to it not being eaten before the use by date, with personal preference and spoilage accounting for the rest. Such avoidable chocolate wastage is responsible for around 90,000 tonnes of greenhouse gas emissions.

Avoiding waste is an obvious way for we consumers to reduce chocolate's climate impact, but our buying habits can also help to determine the sustainability of its global supply chain [10]. Demand has soared in recent decades, bringing increased rates of deforestation and land clearance in many cocoa-growing regions. This is adding to the already carbon-intensive nature of the chocolate life cycle. As emissions rise and climate change intensifies, chocolate is itself in the firing line when it comes to impacts. From cocoa farmers and processors right through to shops and consumers, making chocolate climate-smart may be the only way to secure the future of this most luxurious of foods.

Production of cocoa in its limited climate envelope of consistent rainfall and tropical temperatures has been pushed to its limits by surging demand and prices. The cash-crop that is chocolate has brought vital income and employment to many areas of West Africa and South America, yet increasing climate-variability threatens to undermine this production and so the welfare of the people who rely on it. In Cameroon in 2012, the Government announced plans to more than double cocoa production to 600,000 tonnes by 2020 , providing a huge boost for farmer income and employment. The weather had other ideas.

Instead of reliable rains to recharge soils in the wet season and a dry season in which to harvest and dry the cocoa beans, the rains became more erratic [11]. Unexpected rainfall killed new flowers and blackened young pods, with the pesticides applied to the trees washed away. Farmers were forced to try and smoke-dry their beans and then face roads to market that had become rivers of mud. The unpredictable rains have also meant increased risks of pest and disease attacks-higher rainfall and humidity encouraging fungal diseases like Black Pod [12]. More than one-third of the cocoa harvest in the 2014-15 season was lost due to pests and diseases [11].

Over in Ghana, unreliable rainfall has caused big problems too. In the 2015-16 season the parching Harmattan wind that blows across Ghana from the Sahara Desert came early. With little rainfall and persistent moisture-sapping winds, the cocoa plants suffered poor growth and 
withering of pods in many areas [13]. Things could have been much worse. Given the huge importance of cocoa production in Ghana and the risks to it posed by severe weather events, its Government is already striving to boost resilience. Provision of early-maturing cocoa varieties and improved access to fertilisers have allowed farmers to increase production even in the face of more unreliable rainfall. Importantly, they and other big cocoa-growing nations, like Cote D'Ivoire, are working to understand the risks posed by climate change and help protect the longer-term future of the world's favourite treat.

The prime chocolate belt of cocoa production in West Africa stretches along the coast from Sierra Leone in the west through Cote D'Ivoire, Ghana and Nigeria, to Cameroon in the East. It employs around two million people and provides the world with almost three-quarters of the cocoa we crave. Most is still grown by smallholders who often have to contend with low cocoa prices, ageing trees (that give lower yields), poor access to technology and fertilisers, plus the weather vagaries of a changing climate. Over the last half-century, some areas have already experienced a drop in rainfall of almost one-third, making cocoa production there near impossible. With increasing temperatures and further changes in rainfall due to climate change in coming decades [14], more regions-including some farms in the key cocoa nations of Ghana and Cote D'Ivoire-are at risk of falling yields or even complete loss of cocoa production [15].

By the middle of this century annual rainfall across West Africa is not expected to change very much. Precipitation may even increase and the length of the dry season contract in some of the driest areas-giving a potential boost to cocoa trees. It is water availability, however, not rainfall, that is crucial for the plants. As temperatures rise, so water lost through evaporation increases. For some of the driest cocoa-growing areas in West Africa this means that, even with more rainfall, the amount of water actually available to the plants is reduced and drought impacts become more likely. By the middle of the century the climate envelope for cocoa is expected to contract southwards as drier, savannah-type conditions push down from the north. For big producers like Ghana, growers in the south should still do fine, but in northern areas across the West African chocolate belt a warmer future is set to make cocoa farming a whole lot harder. 
Higher temperatures may also have a direct impact on cocoa. Cocoa plants grow best at between in the low to mid-20s Celsius. They can withstand temperatures of up to 38 degrees Celsius, but such high temperatures slow plant growth and damage pod development. As global temperatures increase, so does the risk that extreme heat wave events will cut cocoa yields in West Africa [15].

Predicting the impacts of climate change on chocolate production means understanding more than just the future climate envelope where growing cocoa will be possible. The farming systems and tree types, the global markets and competition, and the cocoa workers themselves, all are crucial in determining just how big a risk climate change poses. For the two million or so smallholder cocoa growers in Ghana and Cote D'Ivoire, average production currently reaches just half of its potential. Drops in productivity or market price can therefore put huge numbers of people at risk-over six million people in Ghana alone rely in some way on the cocoa industry. One of the reasons for low cocoa yields in Ghana is the old age of many of its cocoa trees. Yields peak at 18 years of age, and almost a quarter of the cocoa trees in Ghana are over 30 years old [16].

Widespread infection by diseases, such as the Cocoa Swollen Shoot Virus, is another concern. This disease is spread via mealy bugs that feed on the cocoa plants. It is thought that it was first transferred into cocoa plants when natural forests were cleared and its mealy bug vectors adopted the cocoa trees as their new hosts [17]. Swollen shoot virus causes leaves to become blotchy and lose their colour. As the infection spreads, the leaves sometimes develop red veins, the shoots and roots develop swellings, and the new shoots begin to die [18]. With severe infections cocoa yields can plummet by as much as 70 per cent and it can kill the whole tree within two or three years of infection [17]. Around 300 million cocoa trees are now thought to be infected, with the only effective treatment available to most farmers being complete destruction (burning) of the diseased trees and replanting with new, disease-free stock [19].

So, the future impacts of climate change on cocoa production-like higher temperatures and lower water availability in some areas of West Africa-are set to compound existing issues like old trees and endemic disease. This bitter recipe risks the livelihoods of millions of people and heaps extra pressure on land use-driving further deforestation and carbon emissions. Deforestation rates in Ghana and Cote D'Ivoire are some of the highest in the world, with over two million hectares of forest having been cleared for cocoa between 1988 and 2007 [5]. Unless cocoa farming 
in West Africa can be made more climate-resilient, our global chocolate addiction will mean even more climate-risk.

Climate-smart chocolate is already becoming a reality in Ghana and Cote D'Ivoire. Our own buying choices and greater awareness of the deforestation risks of cocoa production are helping to alter the practices of big chocolate companies and their suppliers [20]. More attention and support are being focused on the legion of smallholders that are the backbone of the cocoa industry. Here, helping farmers to increase productivity on their existing land, so as to avoid clearance of forest for new planting, is a prime focus. Firstly, rehabilitation of the existing cocoa trees through improving soils, fertiliser use, and better pest and disease control aims to boost their yields. So-called renovation of the cocoa is also encouraged, with replacement of old trees with younger disease-free ones that can gradually improve overall yields and give greater resilience in the future.

A big step in driving such change has been the growing commitment by the global chocolate industry to put an end to deforestation associated with the cocoa they use. Over 60 per cent of the world's cocoa is now supplied via companies with some level of commitment to tackle deforestation. To date, the success of this in actually curtailing deforestation has been questioned [21], yet the momentum for change is growing. Importantly, major chocolate players like Nestle, Hershey and Mars, and big retailers like Tesco and Marks \& Spencer have signed up to the Cocoa \& Forests Initiative [22]. Alongside national governments, this initiative sets out a framework within which all these cocoa stakeholders work both to end deforestation and to restore already degraded forest areas.

It is estimated that almost 2 million hectares of cocoa-growing land in Ghana and Cot D'Ivoire would benefit from rehabilitation-an area roughly the size of Belgium, with a further 1.3 million hectares likely needing some level of renovation [5]. Providing the huge number of good quality, disease-free cocoa seedlings that are now required across Ghana and Cote D'Ivoire is a big challenge. Many small holders don't have access to these (or don't know they do), even if they wanted to start replacing old trees for new ones right away. Where new seedlings have been supplied, there have been problems with mislabelling, damage in transport and delivery at times of the year when the new seedlings have little chance of success. 
Ghana's government-owned cocoa board (Cocobod) controls all seed and seedling production, but its capacity is limited and it still has a long way to go before it can deliver replanting in the estimated one million hectares that need it. Ramping up such provision, by expanding cocoa plant nurseries and improving seedling distribution systems, has the potential to accelerate progress towards more productive and resilient cocoa growing.

For those areas at most risk from heat and drought impacts under a changing climate, the supply of new seedlings to farmers will need to extend beyond just healthy cocoa plants. Here, provision of other trees and plants that can be used to provide smallholders with shade for their cocoa, a source of timber, or to give an extra crop-like avocados-will become increasingly important [23]. The practice of growing shade trees alongside cocoa in Ghana has expanded in recent years as more farmers have experienced first-hand the threats posed by extreme drought and heat. Such shade cocoa can also reduce weed growth and, if combined with nitrogen-fixing trees, boost soil fertility. Its benefits are not a given though. By definition, shade cocoa means less light reaches the cocoa trees. In dry regions this can give vital protection from extreme heat and create a better microclimate in which the cocoa pods can develop. In wetter regions, where such heat and drought resilience are less important, the climate benefits of shade cocoa may be outweighed by slower growth rates, an increase in some diseases (like Black Pod disease), and reduced yields.

On some farms, even with rehabilitation, renovation and shade trees, cocoa's days are numbered. In these drier, already-marginal cocoa areas many smallholders now grow food crops, such as maize and vegetables, in rotation with their cocoa to supplement incomes. As the viable climate envelope for cocoa shifts away southwards, so such smallholders will need help to further diversify into non-cocoa livelihoods.

Knowing where and when such shifts will occur is vital for planning and pro-active adaptation. Really precise climate projections remain some way off - the climate models still struggle to deal with the kind of local scales and specific timings most relevant to smallholder cocoa farmers. Instead, information on larger scale, longer-term changes can be used to inform government plans and wider climate-smart strategies.

For the cocoa farmers themselves, addressing the current dearth of climate services, like provision of education, finance and training, is a prime target for helping to deliver widespread climate-smart improvements. Access to weather forecasts and climate information can reduce some of 
the risks posed by droughts and heat waves. Likewise, advice and support on choices of cocoa tree, how to best cultivate and prune them, and the ways in which to use pesticides (both to protect from disease and to avoid pollution), can improve productivity and resilience. Initiatives like Farmer Field Schools-where farmers share good practice and can access such advice and support [24] — have already proved successful in boosting the skills, yields and livelihoods of Ghana's farmers [25].

The huge scale of change required to deliver a productive, climatesmart cocoa future for Ghana requires a similarly large step-change in farmer knowledge and training. It also requires money. Most cocoa farmers in Ghana cannot access finance and, therefore, often cannot afford the upfront costs and gaps in income that arise from replanting or diversifying to other crops. Unlocking cheaper finance for these farmers, such as through government support, financial training and mobile phone technologies, could help to unblock this major bottleneck for sustainable cocoa across West Africa.

\section{REFERENCES}

1. Nehlig, A. The neuroprotective effects of cocoa flavanol and its influence on cognitive performance. Br. J. Clin. Pharmacol. 75, 716-727 (2013).

2. Statista.com. Retail Consumption of Chocolate Confectionery Worldwide from 2012/13 to 2018/19 (in 1,000 Metric Tons). https://www.statista.com/statistics/238849/global-chocolate-consumption/ (2018).

3. Mintel. Sweet Success for Seasonal Chocolate. http://www.mintel.com/presscentre/food-and-drink/sweet-success-for-seasonal-chocolate (2017).

4. ICCO. Origins of Cocoa and Its Spread Around the World. International Cocoa Organization. https://www.icco.org/about-cocoa/growing-cocoa.html (2013).

5. Kroeger, A., Koenig, S., Thomson, A. \& Streck, C. Forest-and Climate-Smart Cocoa in Côte d'Ivoire and Ghana: Aligning Stakeholders to Support Smallholders in Deforestation-Free Cocoa (World Bank, 2017).

6. Ritchie, H. Global cocoa bean production, 2014. Ourworldindata.org. https://ourworldindata.org/grapher/cocoa-bean-production (2018).

7. Ntiamoah, A. \& Afrane, G. Appropriate Technologies for Environmental Protection in the Developing World 35-41 (Springer, 2009).

8. Mintel. Nation of Chocoholics: Eight Million Brits Eat Chocolate Every Day. http://www.mintel.com/press-centre/food-and-drink/nation-of-chocoholics-eight-million-brits-eat-chocolate-every-day (2014).

9. WRAP. Household food and drink waste in the United Kingdom 2012. Waste and Resource Action Programme. http://www.wrap.org.uk/sites/files/wrap/ hhfdw-2012-main.pdf.pdf (2013). 
10. kakaoplattform.ch. Joint Forces for a Sustainable and Attractive Cocoa Sector. https://www.kakaoplattform.ch/en/ (2018).

11. Ngalame, E. N. Extreme weather threatens Cameroon's hopes of becoming a cocoa giant. Reuters. https://www.reuters.com/article/us-cameroon-climatechange-cocoa/extreme-weather-threatens-cameroons-hopes-of-becominga-cocoa-giant-idUSKBN18Y1ON (2017).

12. Nkobe, M. K., Mulua, S. I., Armathée, A. J. \& Ayonghe, S. N. Impacts of climate change and climate variability on cocoa (Theobroma cacao) yields in meme division, south west region of Cameroon. J. Cameroon Acad. Sci. 11 (2013).

13. Kpodo, K. Harsh winds, lack of rain to hit Ghana cocoa output. Reuters. https://www.reuters.com/article/ghana-cocoa-harmattan/harsh-windslack-of-rain-to-hit-ghana-cocoa-output-idUSL8N15N3QR (2016).

14. Carbonbrief. Mapped: How every part of the world has warmed-And could continue to warm. Carbonbrief.org. https://www.carbonbrief.org/mappedhow-every-part-of-the-world-has-warmed-and-could-continue-to-warm (2018).

15. Schroth, G., Läderach, P., Martinez-Valle, A. I., Bunn, C. \& Jassogne, L. Vulnerability to climate change of cocoa in West Africa: Patterns, opportunities and limits to adaptation. Sci. Total Environ. 556, 231-241 (2016).

16. Kongor, J. E. et al. Constraints for future cocoa production in Ghana. Agroforest. Syst., 1-13 (2017).

17. Cilas, C., Goebel, F.-R., Babin, R. \& Avelino, J. Climate Change and Agriculture Worldwide 73-82 (Springer, 2016).

18. Dzahini-Obiatey, H. \& Fox, R. Early signs of infection in Cacao Swollen Shoot Virus (CSSV) inoculated cocoa seeds and the discovery of the cotyledons of the resultant plants as rich sources of CSSV. Afr. J. Biotechnol. 9 (2010).

19. Andres, C. et al. Agroforestry systems can mitigate the severity of Cocoa Swollen Shoot Virus disease. Agric. Ecosyst. Environ. 252, 83-92 (2018).

20. Ionova, A. How fair is our food? Big companies take reins on sourcing schemes. Reuters. https://www.reuters.com/article/us-food-fairtrade-sustainabilityinsight/how-fair-is-our-food-big-companies-take-reins-on-sourcing-schemesidUSKCNIBE0GI (2017).

21. Maclean, R. Chocolate industry drives rainforest disaster in Ivory Coast. The Guardian. https://www.theguardian.com/environment/2017/sep/13/chocolate-industry-drives-rainforest-disaster-in-ivory-coast (2017).

22. Nieburg, O. The final cut: What can the chocolate industry really do to halt cocoa deforestation? Confectionery News. https://www.confectionerynews. com/Article/2017/09/27/Cocoa-deforestation-What-can-the-chocolateindustry-really-do (2017). 
23. Abdulai, I. et al. Characterization of cocoa production, income diversification and shade tree management along a climate gradient in Ghana. PLoS One 13, e0195777 (2018).

24. FAO. Global Farmer Field School Platform. http://www.fao.org/farmer-fieldschools $/$ en $/$ ?utm_source=twitter\&utm_medium $=$ social + media\&utm campaign=faoknowledge (2018).

25. Okorley, E. L., Adjargo, G. \& Bosompem, M. The potential of farmer field school in cocoa extension delivery: A Ghanaian case study. J. Int. Agri. Exten. Edu. 21, 32-44 (2014).

Open Access This chapter is licensed under the terms of the Creative Commons Attribution 4.0 International License (http://creativecommons.org/licenses/ by $/ 4.0 /$ ), which permits use, sharing, adaptation, distribution and reproduction in any medium or format, as long as you give appropriate credit to the original author(s) and the source, provide a link to the Creative Commons licence and indicate if changes were made.

The images or other third party material in this chapter are included in the chapter's Creative Commons licence, unless indicated otherwise in a credit line to the material. If material is not included in the chapter's Creative Commons licence and your intended use is not permitted by statutory regulation or exceeds the permitted use, you will need to obtain permission directly from the copyright holder.

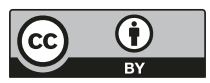

